\title{
Bilayer broadband antireflective coating to achieve planar heterojunction perovskite solar cells with 23.9\% efficiency
}

\author{
Yalun Wang ${ }^{\dagger}$, Hui Wang ${ }^{\dagger}$, Mengting Chen, Pang Wang, Yuchao Mao, Wenjiao Han, Tao Wang and \\ Dan Liu*
}

\begin{abstract}
Although perovskite solar cells (PSCs) have achieved encouraging efficiency, the photon loss at the substrate due to light reflection has not been well addressed. Light management is promising to reduce reflection loss and realize higher power conversion efficiency (PCE) of PSCs. Here, a bilayer antireflective coating (ARC) has been designed and coated onto the backside of the glass substrate of $\left(\mathrm{FAPbI}_{3}\right)_{x}-$ $\left(\mathrm{MAPbBr}_{3}\right)_{1-x}$ PSCs to enhance photon harvesting and consequently the device efficiency. The bottom layer of the bilayer ARC is made from a silica polymer and the top layer is made from the mixture of hexamethyldisiloxane-modified mesoporous silica nanoparticles and a fluorinated silica polymer. By adjusting the refractive index and the film thickness of each layer according to a two-layer model, enhanced glass transmittance in a broadband wavelength range can be reached, with the maximum transmittance increasing from ca. $\mathbf{9 0 \%}$ to over $95 \%$. With the bilayer ARC, the maximum short-circuit current density and PCE of $\left(\mathrm{FAPbI}_{3}\right)_{x}\left(\mathrm{MAPbBr}_{3}\right)_{1-x}$ PSCs can be increased from $25.5 \mathrm{~mA} \mathrm{~cm}^{-2}$ and $22.7 \%$ to $26.5 \mathrm{~mA} \mathrm{~cm}^{-2}$ and $23.9 \%$ with negligible changes in fill factor and opencircuit voltage. This work presents a simple yet effective strategy to enhance the efficiency of solar cells employing bilayer antirefective coatings, which can be applied to other types of solar cells.
\end{abstract}

Keywords: mesoporous silica nanoparticles, antireflective coating, perovskite solar cells, efficiency

\section{INTRODUCTION}

Organic-inorganic halide perovskite materials have strong light absorption, long carrier diffusion length and high carrier mobility, which are characteristics to realize high-performance photovoltaic devices $[1,2]$. The record efficiency of perovskite solar cells (PSCs) now is $25.2 \%$ after only ten years development and is comparable to the efficiency of commercial silicon solar cells [3].

Many strategies, including energy level alignment [46], additive engineering [7-9] and defect passivation [1012], have been explored to further enhance the efficiency of PSCs. For example, Wang et al. [4] added an $\operatorname{In}_{2} \mathrm{O}_{3}$ layer on top of the $\mathrm{SnO}_{2}$ electron transport layer to tune the energy level alignment of the perovskite layer. The $\mathrm{In}_{2} \mathrm{O}_{3}$ layer not only promotes the electron transport at the interface, but also increases the open-circuit voltage $\left(V_{\mathrm{OC}}\right)$, so the power conversion efficiency (PCE) of the resultant PSC can reach $23.24 \%$. Kim et al. [13] added methylammonium chloride additive into the perovskite layer, and reported a PCE of $23.48 \%$. Jiang et al. [14] found that a phenethylammonium iodide layer, formed on the surface of the perovskite layer, could result in a PCE of $23.32 \%$ by reducing defects and suppressing nonradiative recombination. As encouraging results have been reported, the light reflection loss on the light incidence surface of PSCs has not been solved with satisfaction, which is a significant obstacle for further enhancement of the PCE. Luo et al. [15] recently proposed a creative antireflective method using $\mathrm{SnO}_{2} / \mathrm{TiO}_{2}$ $\mathrm{Cl}$ bilayer as the antireflective, cascaded electron transport layer (ETL) to reduce light loss and enhance device efficiency. However, the materials here should be deliberately designed to match the energy levels at the interface with perovskite, and a precise control of film thickness is also essential to enable antireflection effect, which means that this method may not be universal.

Casting antireflective coating (ARC) onto the back side of the glass substrate of PSCs is a simple and practical

School of Materials Science and Engineering, Wuhan University of Technology, Wuhan 430070, China

${ }^{\dagger}$ These authors contributed equally to this work.

* Corresponding author (email: dliu@whut.edu.cn) 
light-management method to increase photon entry into the photoactive layers, and thereby enhances the efficiency of photovoltaics [16]. Mesoporous silica nanoparticles (MSNs) have been widely employed as antireflective materials due to its low refractive index $(<1.2)$. Although a single layer ARC could be simply casted by spin-coating the MSN suspension [17,18], the transmittance is limited by the angle and wavelength range of the incident light [19-21]. To minimize light reflection in a broadband or even full wavelength range, multilayer ARCs and structured ARCs having graded refractive indices have been explored [21]. For example, polydimethylsiloxane (PDMS) nanocone ARC coated on flexible PSCs has been reported to increase the PCE from $12.04 \%$ to $13.14 \%$ [22]. Inverted micro-pyramidal structured PDMS ARC, achieving $95.2 \%$ transmittance of the glass, improved the PCE of $\mathrm{CH}_{3} \mathrm{NH}_{3} \mathrm{PbI}_{3}$-based PSCs from $17.17 \%$ to $17.74 \%$ [23]. Here, the size of the PDMS nanocones and the spacing between each other should be precisely controlled, which is challenging. Trilayer ARC made by solution method can achieve nearly full-transmittance in the visible region [24-26]. Lien et al. [27] reported an increased efficiency of monocrystalline $\mathrm{Si}$ solar cells by $39 \%$ after coating a trilayer ARC $\mathrm{SiO}_{2} / \mathrm{SiO}_{2}-$ $\mathrm{TiO}_{2} / \mathrm{TiO}_{2}$. This trilayer ARC, however, requests high temperature heating of each spin-coated layer, and is therefore not suitable for perovskite which will decompose under those treatments.

Bilayer ARCs, consisting of a lower-refractive-index layer and a higher-refractive-index layer, have more simplified manufacturing process compared with the trilayer ARCs and superior to the single-layer ARC for achieving antireflection over a broadband range if the refractive indices and thicknesses of the two layers can be rationally designed. For instance, Kantarli et al. [28] fabricated ARCs by vacuum evaporation on silicon and reported that the double-layer $\mathrm{ARC}\left(\mathrm{MgF}_{2} / \mathrm{ZnS}\right)$ can produce low reflectance in a broader region than that achieved via a single-layer ARC made of $\mathrm{SiO}, \mathrm{CeO}_{2}$ or $\mathrm{ZnS}$. Li et al. [29] reported a bilayer silica ARC, with nearly full transmittance could be achieved in the wavelength range from 500 to $850 \mathrm{~nm}$. Prené et al. [30] showed that nearly full transmittance between 550 and $850 \mathrm{~nm}$ could be achieved by adjusting the refractive indices of the bottom $\mathrm{Ta}_{2} \mathrm{O}_{5}$ and top $\mathrm{SiO}_{2}$ layers.

In this study, a bilayer ARC was prepared by spincoating in air with low-temperature post-treatment and applied as ARC for PSCs to increase light absorption and device efficiency. The refractive index and thickness of the bottom layer made from silica polymer are 1.42 and ca. $95 \mathrm{~nm}$, respectively. The top layer is made from a mixture of hexamethyldisiloxane-modified MSNs (HMDS-MSNs) [17] and a fluorinated silica polymer. The refractive index and thickness of the top layer are 1.21 and ca. $115 \mathrm{~nm}$, respectively. With the controlled refractive indices and thicknesses, the bilayer ARC could increase the transmittance of the PSCs' glass substrate from ca. $90 \%$ to over $95 \%$ in the range from 488 to $745 \mathrm{~nm}$, and features improved surface hydrophilicity enabled by the fluorinated silica polymer in the ARC2 layer to provide environmental durability. The bilayer ARC was solution-coated on the light incidence side of the glass substrate after the fabrication of PSCs, therefore has no interference to the fabrication of the PSCs. The short-circuit density $\left(J_{\mathrm{SC}}\right)$ and $\mathrm{PCE}$ of the $\left(\mathrm{FAPbI}_{3}\right)_{x^{-}}$ $\left(\mathrm{MAPbBr}_{3}\right)_{1-x}$ PSCs could be enhanced from $25.5 \mathrm{~mA} \mathrm{~cm}^{-2}$ and $22.7 \%$ to $26.5 \mathrm{~mA} \mathrm{~cm}^{-2}$ and $23.9 \%$. The bilayer ARC demonstrated in this work can be applied to other photovoltaic devices, e.g., organic solar cells and quantum-dot solar cells, to improve light absorption of the photoactive layer and consequently enhance the photovoltaic performance.

\section{EXPERIMENTAL SECTION}

\section{Materials}

Tetraethyl orthosilicate (TEOS,>99\%) was purchased from Macklin. Triethanolamine (TEA, AR), hydrochloric acid ( $\mathrm{HCl}, 36 \% \sim 38 \%)$, ethanol, iso-propanol, dimethyl sulfoxide (DMSO) and dimethyl formamide (DMF) were purchased from Shenshi Chemical China. 4-tert-Butylpyridine (TBP), bistrifluoromethanesulfonimide lithium salt (Li-TFSI), $1 \mathrm{H}, 1 \mathrm{H}, 2 \mathrm{H}, 2 \mathrm{H}$-perfluoroalkyltriethoxysilanes, HMDS (99\%) and hexadecyltrimethylammonium bromide (CTAB, 99\%) were purchased from Aladdin. Thiourea, $\quad \mathrm{SnCl}_{2} \cdot 2 \mathrm{H}_{2} \mathrm{O}, \quad \mathrm{PbI}_{2}, \quad \mathrm{CH}_{3} \mathrm{NH}_{3} \mathrm{Cl}$ (MACl), $\mathrm{CH}\left(\mathrm{NH}_{2}\right)_{2} \mathrm{I}$ (FAI), and $\mathrm{CH}_{3} \mathrm{NH}_{3} \mathrm{Br}$ (MABr) were purchased from Sigma Aldrich. $\mathrm{SnO}_{2}$ quantum dot solution was synthesized as reported [31].

\section{Synthesis and preparation of antireflective coatings}

The silica polymer used to spin-cast the antireflective coating one (ARC1) was synthesized by the reaction of $200 \mu \mathrm{L}$ of TEOS and $50 \mu \mathrm{L}$ of $\mathrm{HCl}(0.1 \mathrm{~mol} / \mathrm{L})$ in $2 \mathrm{~mL}$ of 2-propanol at room temperature for $2 \mathrm{~h}$. The fluorinated silica polymer was synthesized with the above method as well, but with $1 \mathrm{H}, 1 \mathrm{H}, 2 \mathrm{H}, 2 \mathrm{H}$-perfluoroalkyltriethoxysilanes replacing TEOS. The HMDS-MSN suspension was synthesized as reported in our previous study [17]. Here, the HMDS-MSN suspension was blended with the 
fluorinated silica polymer to spin-cast the antireflective coating two (ARC2). The bilayer ARC film was fabricated by spin-coating the as-synthesized solutions in air. The solid concentration of the solutions was adjusted to vary the film thickness which was determined by a spectroscopy ellipsometer (SE) (M2000D, J. A. Woollam Co.). The spin-cast ARC1 layer was heated at $50^{\circ} \mathrm{C}$ for $30 \mathrm{~s}$ to ensure its complete dry before coating the second layer ARC2. The mixture solution of HMDS-MSNs/fluorinated silica polymer is made up of $2.5 \mathrm{wt} \%$ HMDS-MSNs and $6.75 \mathrm{wt} \%$ fluorinated silica polymer, both in 2-propanol and with a volume ratio of $2: 1$. The surface structures of the ARC1 and ARC2 were characterized by scanning probe microscopy (SPM) (Solver NEXT, NT-MDT) and scanning electron microscopy (SEM) (S4800, Hitachi).

\section{Optical modeling}

The TFCalc software was used to fit and analyze the transmittance and reflectance of the glass coated with ARC2 or bilayer ARC. Optical parameters of ARCs, including refractive index and extinction coefficient were measured using SE and analyzed with the Cauchy mode. Other parameters that were added in the optical modeling are shown in Table 1.

\section{Fabrication of the PSCs}

The architecture of the $\left(\mathrm{FAPbI}_{3}\right)_{x}\left(\mathrm{MAPbBr}_{3}\right)_{1-x}$ PSCs from bottom to top is indium tin oxide (ITO) as the cathode, $\mathrm{SnO}_{2}$ layer as the electron transport layer, fullerene dimer (NMBF-Cl dimer) as the interfacial layer, $\left(\mathrm{FAPbI}_{3}\right)_{x}\left(\mathrm{MAPbBr}_{3}\right)_{1-x}$ hybrid perovskite as the photoactive layer, doped spiro-OMeTAD as the hole transport layer and $\mathrm{Ag}$ as the electrode. The fabrication procedures are described herein. After sonication in deionized water, ethanol and isopropyl alcohol in sequence for $10 \mathrm{~min}$ each, the pre-patterned ITO glass substrates (resistance ca. $15 \Omega$ per square) were dried at $100^{\circ} \mathrm{C}$ on a hotplate and subsequently treated with UV/Ozone for $15 \mathrm{~min}$. Then the $\mathrm{SnO}_{2}$ quantum dot solution was spin-coated onto the ITO glass at a speed of $3000 \mathrm{rpm}$ for $30 \mathrm{~s}$ and annealed at $200^{\circ} \mathrm{C}$ for $60 \mathrm{~min}$, and subsequently treated with UV/Ozone for $10 \mathrm{~min}$. A layer of NMBF-Cl dimer was spin-coated on top of $\mathrm{SnO}_{2}$ as an interfacial layer.

The $\mathrm{PbI}_{2}$ solution (642.6 mg dissolved in the mixture of $940 \mu \mathrm{L}$ of DMF and $60 \mu \mathrm{L}$ of DMSO) was stirred at $60^{\circ} \mathrm{C}$ on a hotplate until thorough dissolution. The perovskite precursors, $\mathrm{FAI}, \mathrm{MABr}$ and $\mathrm{MACl}$ (weight ratio of 80:5:9), were dissolved in 2-propanol with a concentration of $94 \mathrm{mg} \mathrm{L}^{-1}$. The perovskite film was prepared by a two-step method. First, $30 \mu \mathrm{L}$ of $\mathrm{PbI}_{2}$ solution was spin-
Table 1 The modeling factors and values

\begin{tabular}{cc}
\hline Modeling Factors & Values \\
\hline Reference wavelength $(\mathrm{nm})$ & 550 \\
Illuminant & White \\
Incident angle $\left(^{\circ}\right)$ & 0.0 \\
Incident medium & Air \\
Substrate & Glass \\
Thickness (mm) & 1.0 \\
Exit medium & Air \\
Detector & Ideal \\
First surface & Front \\
\hline
\end{tabular}

coated at a speed of $2000 \mathrm{rpm}$ for $30 \mathrm{~s}$, and then annealed at $70^{\circ} \mathrm{C}$ for $1 \mathrm{~min}$. After cooling to room temperature, $50 \mu \mathrm{L}$ of the mixture of $\mathrm{FAI}, \mathrm{MABr}$ and $\mathrm{MACl}$ was spincoated on the $\mathrm{PbI}_{2}$ film at a speed of $2200 \mathrm{rpm}$ for $15 \mathrm{~s}$. The above fabrication was performed in a nitrogen-filled glovebox. Subsequently, the films were taken into $40 \%$ humidity air and annealed at $150^{\circ} \mathrm{C}$ for $15 \mathrm{~min}$. Finally, smooth and black perovskite films were obtained.

To prepare the spiro-OMeTAD hole transport layer, $17.5 \mu \mathrm{L}$ of Li-TFSI acetonitrile solution $\left(520 \mathrm{mg} \mathrm{mL}^{-1}\right)$ and $28.5 \mu \mathrm{L}$ of TBP as dopants were firstly added into $1 \mathrm{~mL}$ of spiro-OMeTAD solution $\left(80 \mathrm{mg} \mathrm{mL}^{-1}\right)$. The mixture was spin-coated on the perovskite layer at a speed of $4000 \mathrm{rpm}$ for $30 \mathrm{~s}$. After16-h oxidation in a glass dryer, the Ag electrode was thermally evaporated onto the hole transport layer under high vacuum through the shadow mask. Each device consisted of 8 pixels, and the size of each pixel, determined by the anode and cathode, was $4 \mathrm{~mm}^{2}$. Finally, all PSC devices without any encapsulation were moved out of the glovebox for current density-voltage $(J-V)$ and external quantum efficiency (EQE) measurements. Specifically, the $J-V$ characterization was performed under AM $1.5 \mathrm{G}\left(100 \mathrm{~mW} \mathrm{~cm}^{-2}\right)$ employing a Newport 3A solar simulator (Newport, USA) and a source meter unit (2612B, Keithley, USA) with a $J$ $V$ scanning software (Ossila Ltd., UK), which was further calibrated with an NREL-certified silicon reference cell before the measurement. The devices were masked with a metal aperture mask to accurately define the testing area on each pixel, and to eliminate the influence of stray and wave guided light. EQE employed an EQE system (Zolix, China) with the monochromatic beam generated from a $150-\mathrm{W}$ xenon lamp. The bilayer ARC was coated on the outside of the glass substrate after the fabrication of PSC, and device performance was tested before and after the coating of the bilayer ARC for comparison. 


\section{RESULTS AND DISCUSSION}

The synthesis of HMDS-MSNs, as schemed in Fig. 1a, follows our previous report [17]. The syntheses of silica polymer and fluorinated silica polymer are described in the experimental section and outlined in Fig. 1b, c. The bilayer ARC, coated on the back side of PSCs (see Fig. 1d), consists of ARC1 prepared by spin-coating the silica polymer solution, and ARC2 prepared by spincoating the mixture of the fluorinated silica polymer and HMDS-MSNs.

The surface structures of the ARC1 and ARC2 probed by SPM and SEM are shown in Fig. 2. The ARC1 made from the silica polymer is smooth and flat, as evidenced by the SEM image (Fig. 2d) and especially the SPM image in Fig. 2a having a root mean square (RMS) surface roughness of $0.3 \mathrm{~nm}$ only. The ARC2 layer made from the mixture of HMDS-MSNs and the fluorinated silica polymer was spin-coated on bare glass and ARC1, respectively, and their SPM images are shown in Fig. 2b, c. Marginal difference could be identified from the two images, with the RMS of ARC2 coated on glass and ARC1 around $25 \mathrm{~nm}$, close to the average particle size of around $25 \mathrm{~nm}$ of HMDS-MSNs. The underneath ARC1 therefore will not affect the film formation of the ARC2, but promote the adhesion between ARC2 and the glass to enhance the mechanical durability of the bilayer ARC, since ARC1 has a relatively low glass transition temperature compared with ARC2. The roughness of bilayer ARC layer is far less than the visible wavelength and will not cause serious light scattering. Compared with the ARC prepared with the mixture of HMDS-MSNs and silica polymer in our previous study [17], the bilayer ARC here has increased hydrophobicity due to the fluorinated silica polymer. The water contact angle (WCA) image of the bilayer ARC is shown as inset in Fig. 2e, and a high WCA of $133^{\circ}$ (compared with a WCA of $12^{\circ}$ for the ARC1 layer only) ensures a good environmental durability of this bilayer ARC.

In a single-layer design for ARC, the refractive index of ARC should meet $n_{\text {arc }}=\sqrt{n_{\text {air }} n_{\mathrm{s}}}$, where $n_{\text {arc }}, n_{\text {air }}$ and $n_{\mathrm{s}}$ are the refractive indices of ARC, air and substrate, re-
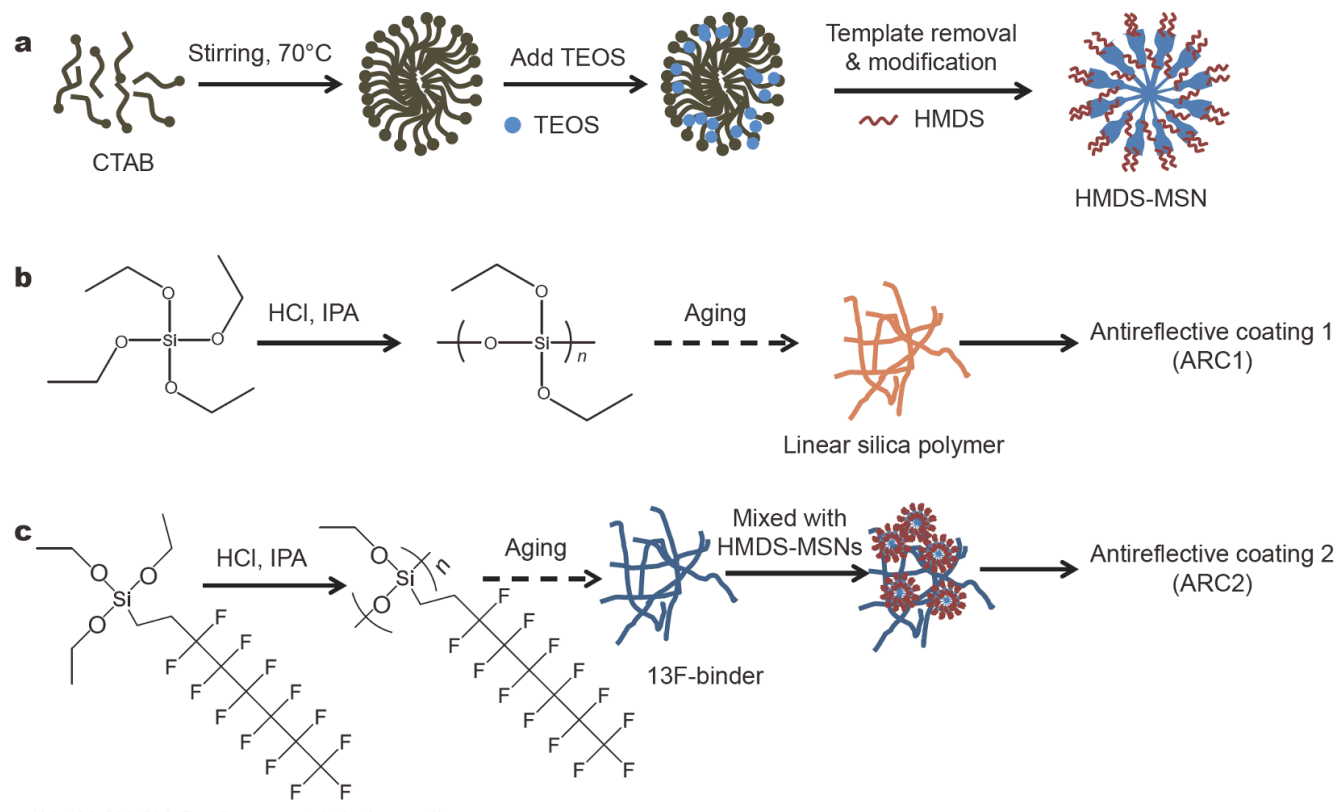

$1 \mathrm{H}, 1 \mathrm{H}, 2 \mathrm{H}, 2 \mathrm{H}-\mathrm{Perf}$ luorooctyltriethoxysilane
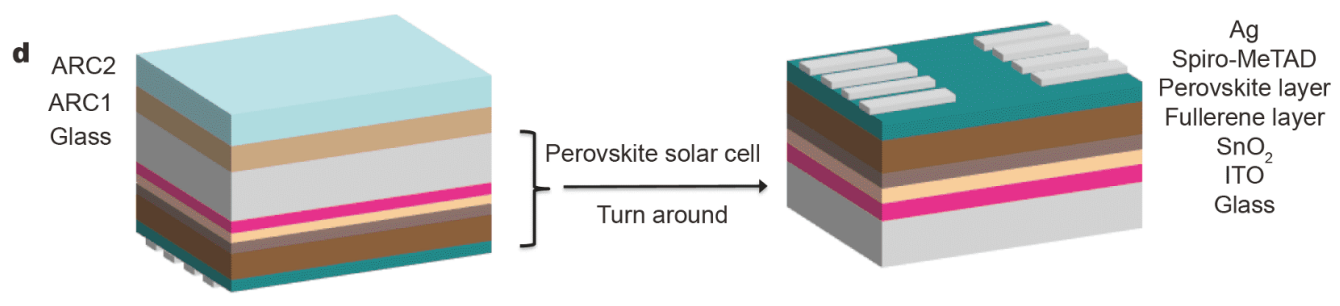

Figure 1 The synthesis routes of (a) HMDS-MSNs, (b) silica polymer and (c) fluorinated silica polymer, and (d) the device architecture of the PSCs coated with the bilayer ARC. 

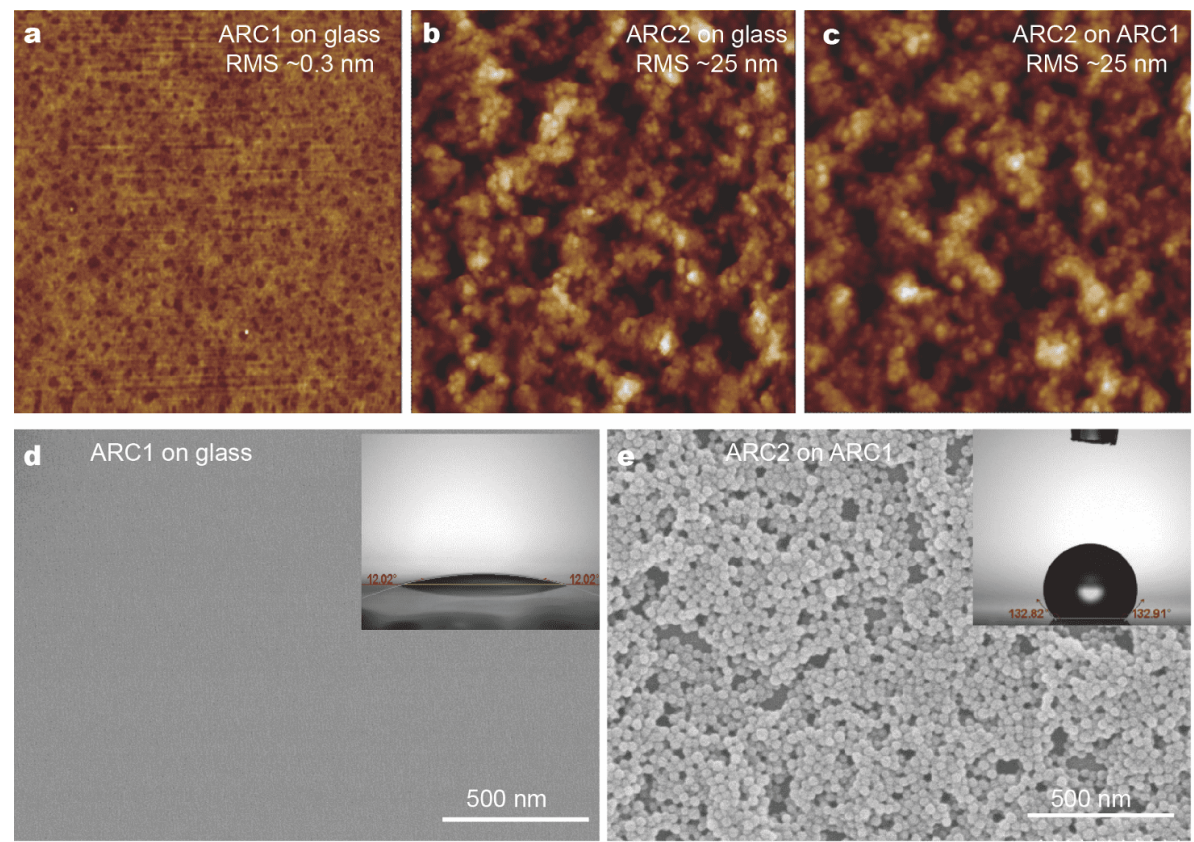

Figure 2 SPM images of the (a) ARC1 layer, (b) ARC2 layer coated on glass and (c) ARC2 layer coated on ARC1. SPM image sizes are $5 \mu \mathrm{m} \times 5 \mu \mathrm{m}$. SEM images of (d) ARC1 layer and (e) ARC2 layer coated on ARC1. The insets in (d) and (e) show the water contact angle images of ARC1 and ARC2 coated on ARC1.

spectively [17]. The refractive index of ARC2 almost meets this equation and therefore shows an antireflective effect in a relatively narrow range around $550 \mathrm{~nm}$, as evidenced by our experimental measurement shown in Fig. 3a. However, the transmittance of the single ARC2 layer coated on glass reduces in the short-wavelength range and especially in the long-wavelength range. Accordingly, the reflectance of the single ARC2 layer is high in both the short- and long-wavelength ranges, as shown in Fig. 3b. This marks the advantage as well as limit of single layer design of ARC to enhance the light absorption and solar cell efficiency, as demonstrated in our previous study on organic solar cells [17].

According to the theory of ARC on a low-index substrate [32], the refractive index of ARC1 $\left(n_{1}\right)$ and ARC2 $\left(n_{2}\right)$ should meet $n_{2}=n_{1} \sqrt{n_{\text {air }} / n_{\mathrm{s}}}$, and the optical thickness of each layer should be around a quarter of the center wavelength $(550 \mathrm{~nm})$ of the incident light, i.e., $\lambda / 4$, to enable a broadband antireflective effect of the bilayer ARC $[29,33]$. The refractive indices of ARC1 and ARC2 are 1.42 and 1.21, respectively, according to the $\mathrm{SE}$ measurements, which satisfy the above equation. The above refractive indices also set the physical thickness of ARC1 and ARC2 to be around 95 and $115 \mathrm{~nm}$, respectively. The solid contents of each ARC solution and the spin speed should be tuned to receive the targeted film coating with a wide window of solid content or spin speed existing to offer flexibility.

Once the refractive index and thickness of each ARC layer have been tuned to optimize light transmittance, the antireflective effect of the bilayer ARC in a broader wavelength can be achieved. Fig. 3a, b show that the bilayer ARC can significantly increase the transmittance (or reduce the reflectance) of glass in a broader wavelength range than the effect of a single-layer ARC2. The max transmittance of the glass coated with the bilayer ARC is over $95 \%$ at $550 \mathrm{~nm}$, and remains high in both short- and long-wavelength ranges. The reason for not achieving the full transmittance or zero reflectance is that the bilayer ARC is coated on one side rather than both sides of the glass [34]. We also employed software TFCalc [24,25,35] to calculate the transmittance and reflectance of the glass coated with the bilayer ARC to verify our experimental results. The refractive index and thickness obtained by SE measurements were introduced into the model to start the calculation. The details of modeling parameters are shown in Table 1. As shown in Fig. 3a, b, the model fitted results match relatively well with our experimental results, although minor deviations between modeling and experiment can be observed. The main reason is that the 

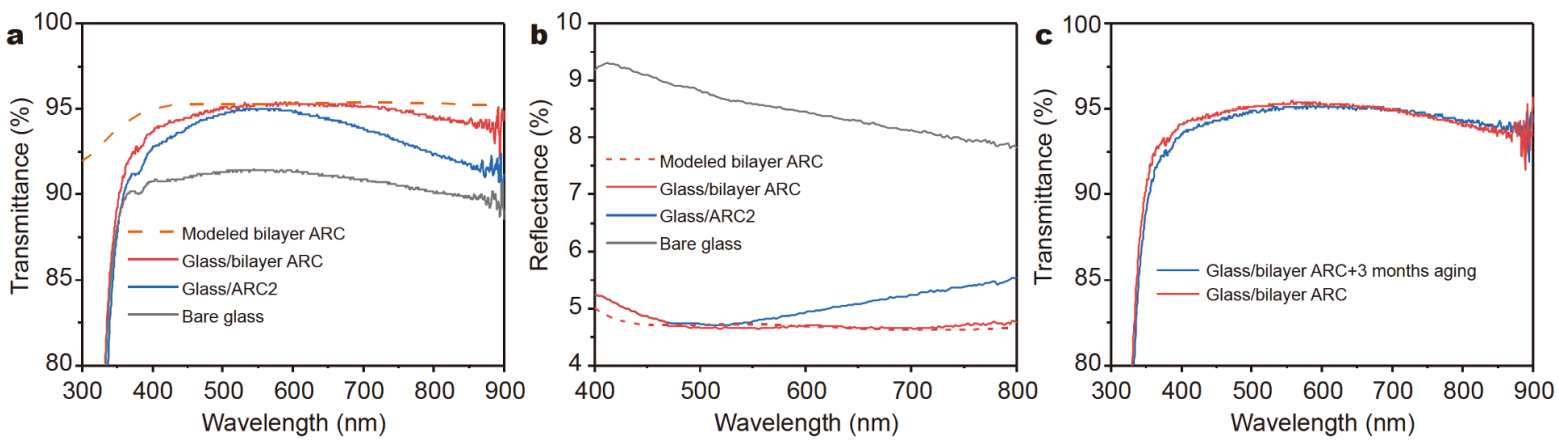

Figure 3 (a) Transmittance and (b) reflectance of the glass, glass coated with the single-layer ARC2 and bilayer ARC. (c) Transmittance of the fresh bilayer ARC and that after 3 month aging.

absorptions of glass and bilayer ARC have not been considered in the TFCalc calculation. As an examination of the environmental durability of the bilayer ARC, the transmittance of the glass coated with the bilayer ARC was measured again after 3 month aging and marginal reduction can be found in Fig. 3c, suggesting good durability in air.

The bilayer ARC was then coated on the outside of the glass substrates of PCSs (see device architecture in Fig. 1d), with $\left(\mathrm{FAPbI}_{3}\right)_{x}\left(\mathrm{MAPbBr}_{3}\right)_{1-x}$ hybrid perovskite as the light absorber. Each PSC fabricated on a single glass substrate was pixelated to eight individual subdevices, each of which can operate separately and therefore can be employed to evaluate the uniformity of bilayer ARC at different locations of a glass substrate. All PSCs before and after coating with the bilayer ARC were measured under simulated one sun with a light intensity of $100 \mathrm{~mW} \mathrm{~cm}{ }^{-2}$. Representative $J-V$ curves of $\left(\mathrm{FAPbI}_{3}\right)_{x}$ $\left(\mathrm{MAPbBr}_{3}\right)_{1-x}$ PSCs are plotted in Fig. $4 \mathrm{a}$, and the average and maximum photovoltaic parameters $\left(U_{\mathrm{SC}}\right.$, fill factor (FF), $V_{\mathrm{OC}}$ and PCE) are summarized in Table 2. The reference device without the bilayer ARC delivers a maximum PCE of 22.7\%, with an average $J_{\text {SC }}$ of $25.3 \pm 0.3 \mathrm{~mA} \mathrm{~cm}^{-2}$, FF of $75.8 \pm 4.1 \%, V_{\mathrm{OC}}$ of $1.07 \pm 0.04 \mathrm{~V}$ and PCE of $20.5 \pm 1.6 \%$. This decent device performance is due to the strong light absorption of the $\left(\mathrm{FAPbI}_{3}\right)_{x}$ $\left(\mathrm{MAPbBr}_{3}\right)_{1-x}$ hybrid perovskite, and is hysteresis-free benefiting from the dual defect-passivation function of the NMBF-Cl dimer interlayer to both $\mathrm{SnO}_{2}$ and perovskite layer, as reported in our recent study [36]. With the bilayer ARC, the average $J_{\mathrm{SC}}$ of PSCs is enhanced to $26.3 \pm 0.3 \mathrm{~mA} \mathrm{~cm}^{-2}$, with the $\mathrm{FF}$ and $V_{\mathrm{OC}}$ almost unchanged, resulting in an average PCE of $21.6 \pm 1.6 \%$ with a maximum of $23.9 \%$. The enhanced $J_{S C}$ of PSC is due to the improved light absorption of the perovskite layer for the antireflective effect of the bilayer ARC in a broadband wavelength (see Fig. 3a), supported by the EQE spectra presented in Fig. 4b. The intensity of the EQE spectrum is enhanced in the wavelength range from 300 to $800 \mathrm{~nm}$, indicating the enhanced photon to electricity conversion. The calculated $J_{\mathrm{SC}}$ from the integration of the EQE spectra is also summarized in Table 2, which are found about 7\% less than the $J_{\mathrm{SC}}$ obtained from the $J-V$ curves. This discrepancy is an intrinsic result of the difference between the illumination conditions, as EQE measurement employs monochromatic light at a single wavelength, while $J$ - $V$ sweep employs simulated full spectrum sun light [37].

The photovoltaic parameters of all eight pixels sharing the same ITO glass are plotted in Fig. 4c-f. Compared with the PSC without the bilayer ARC, enhanced $J_{\mathrm{SC}}$ on all eight pixels can be observed, with the $\mathrm{FF}$ and $V_{\mathrm{OC}}$ almost unchanged. The ARC layer is coated outside of the PSC and will not interfere with the photon to electricity conversion process of PSCs, except allowing more photons to reach the perovskite layer and be absorbed. The average $J_{\mathrm{SC}}$ increment is about $4 \%$, and is close to the transmittance improvements shown in Fig. 3a. The testing of performance on different pixels of device fabricated on a single glass substrate demonstrates the uniformity of these solution-processed ARCs and high reproducibility of enhancing device efficiency. Our low-cost, solutionprocessed bilayer ARC locates on the back side of the glass substrate, and therefore does not interfere with the fabrication of the solar cells and can be applied to any type of solar cells, e.g., organic solar cells, PSCs, silicon solar cells and CIGS solar cells, thereby holding promising commercialization potential.

\section{CONCLUSIONS}

A bilayer ARC has been designed, with the bottom layer 

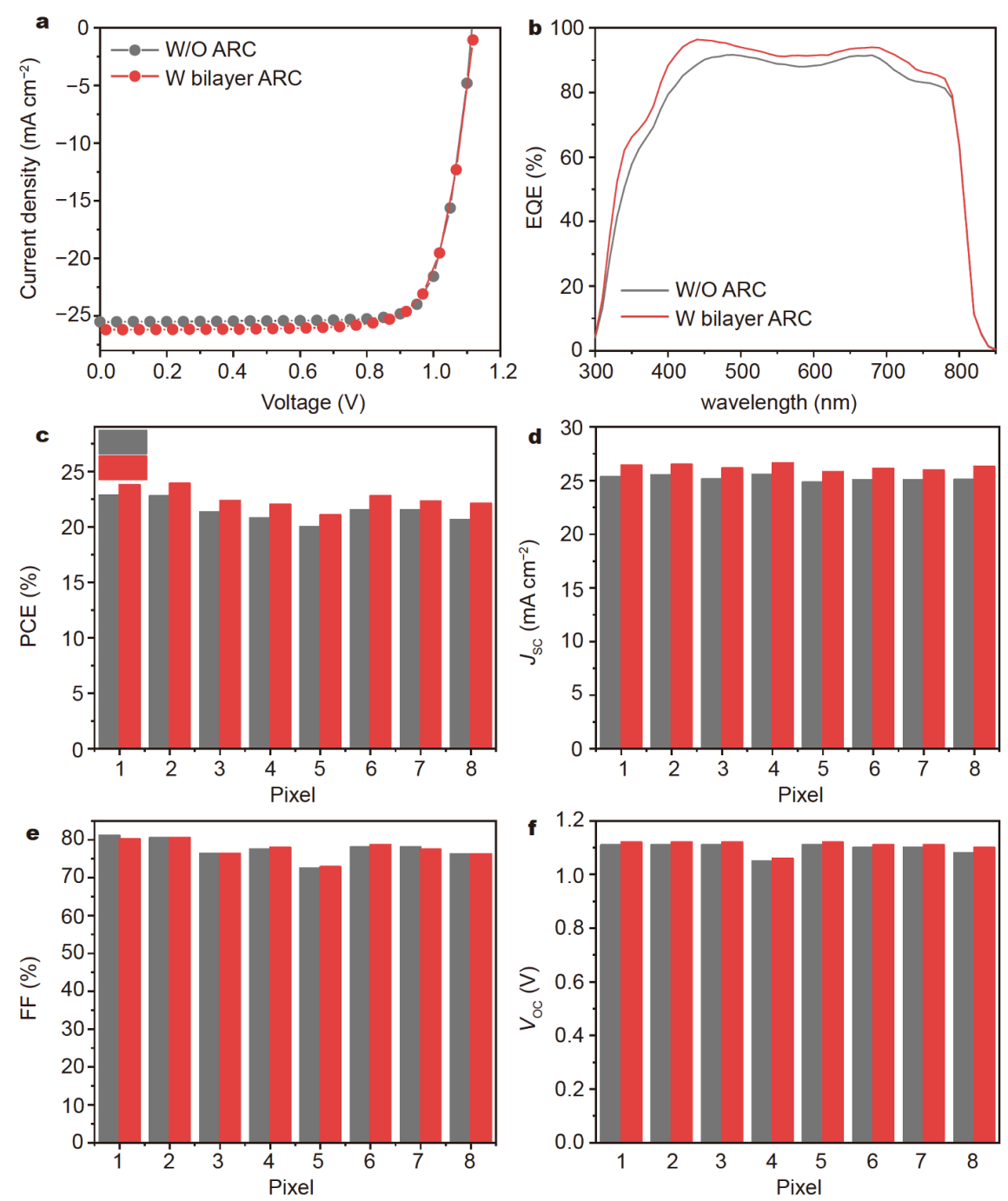

Figure 4 (a) $J-V$ curves and EQE spectra of the $\left(\mathrm{FAPbI}_{3}\right)_{x}\left(\mathrm{MAPbBr}_{3}\right)_{1-x}$ PSCs coated with and without the bilayer ARC. (c) PCE, (d) $J_{\mathrm{SC}}$, (e) FF and (f) $V_{\mathrm{OC}}$ of all eight pixels of a $\left(\mathrm{FAPbI}_{3}\right)_{x}\left(\mathrm{MAPbBr}_{3}\right)_{1-x} \mathrm{PSC}$ with and without the bilayer ARC.

Table 2 Device metrics of the PSCs with and without the bilayer ARC

\begin{tabular}{cccccc}
\hline & $\begin{array}{c}J_{\mathrm{SC}} \\
\left(\mathrm{mA} \mathrm{cm}^{-2}\right)\end{array}$ & $\begin{array}{c}\text { Calculated } J_{\mathrm{SC}} \\
\left(\mathrm{mA} \mathrm{cm}^{2}\right)\end{array}$ & FF $(\%)$ & $V_{\mathrm{OC}}(\mathrm{V})$ & PCE $(\%)$ \\
\hline$\left(\mathrm{FAPbI}_{3}\right)_{x}\left(\mathrm{MAPbBr}_{3}\right)_{1-x}(\mathrm{~W} / \mathrm{O}$ ARC $)$ & $25.5(25.3 \pm 0.3)$ & 23.7 & $80.5(75.8 \pm 4.1)$ & $1.11(1.07 \pm 0.04)$ & $22.7(20.5 \pm 1.6)$ \\
$\left(\mathrm{FAPbI}_{3}\right)_{x}\left(\mathrm{MAPBr}_{3}\right)_{1-x}$ (with bilayer ARC $)$ & $26.5(26.3 \pm 0.3)$ & 24.8 & $80.5(76.2 \pm 3.8)$ & $1.12(1.07 \pm 0.04)$ & $23.9(21.6 \pm 1.6)$ \\
\hline
\end{tabular}

made from a silica polymer and the top layer made from the mixture of HMDS-MSNs and a fluorinated silica polymer. By tuning the refractive index and film thickness of each layer, a bilayer ARC with enhanced transmittance of the glass in a broadband wavelength range has been prepared, with the maximum transmittance being increased from ca. $90 \%$ to $95 \%$. The bilayer ARC was coated on the outside of the glass substrate of PSCs, and found to increase the $J_{\mathrm{SC}}$ about $4 \%$, resulting in an increased maximum (uncertified) PCE from 22.7\% to $23.9 \%$ of the solar cells with a device structure of glass/ $\mathrm{ITO} / \mathrm{SnO}_{2} /$ fullerene $/\left(\mathrm{FAPbI}_{3}\right)_{x}\left(\mathrm{MAPbBr}_{3}\right)_{1-x} /$ Spiro-OMeTAD/Ag. This work presents a simple yet effective strategy to enhance the efficiency of photovoltaic solar 
cells via the light management approach through employing bilayer ARCs.

Received 4 July 2020; accepted 4 August 2020;

published online 22 October 2020

1 Stoumpos CC, Malliakas CD, Kanatzidis MG. Semiconducting tin and lead iodide perovskites with organic cations: Phase transitions, high mobilities, and near-infrared photoluminescent properties. Inorg Chem, 2013, 52: 9019-9038

2 Fang Y, Bi C, Wang D, et al. The functions of fullerenes in hybrid perovskite solar cells. ACS Energy Lett, 2017, 2: 782-794

3 NREL, https://www.nrel.gov/pv/assets/pdfs/best-reserch-cell-efficiencies.pdf (Last access in Feb, 2020)

4 Wang $\mathrm{P}, \mathrm{Li} \mathrm{R}$, Chen $\mathrm{B}$, et al. Gradient energy alignment engineering for planar perovskite solar cells with efficiency over $23 \%$. Adv Mater, 2020, 32: 1905766

5 Gong X, Sun Q, Liu S, et al. Highly efficient perovskite solar cells with gradient bilayer electron transport materials. Nano Lett, 2018, 18: 3969-3977

6 Kim H, Lim KG, Lee TW. Planar heterojunction organometal halide perovskite solar cells: Roles of interfacial layers. Energy Environ Sci, 2016, 9: 12-30

7 Chang CY, Chu CY, Huang YC, et al. Tuning perovskite morphology by polymer additive for high efficiency solar cell. ACS Appl Mater Interfaces, 2015, 7: 4955-4961

8 Chiang CH, Wu CG. Bulk heterojunction perovskite-PCBM solar cells with high fill factor. Nat Photon, 2016, 10: 196-200

9 Sun C, Xue Q, Hu Z, et al. Phosphonium halides as both processing additives and interfacial modifiers for high performance planar-heterojunction perovskite solar cells. Small, 2015, 11: 33443350

10 Chen Q, Zhou H, Song TB, et al. Controllable self-induced passivation of hybrid lead iodide perovskites toward high performance solar cells. Nano Lett, 2014, 14: 4158-4163

11 Wang L, McCleese C, Kovalsky A, et al. Femtosecond time-resolved transient absorption spectroscopy of $\mathrm{CH}_{3} \mathrm{NH}_{3} \mathrm{PbI}_{3}$ perovskite films: evidence for passivation effect of $\mathrm{PbI}_{2}$. J Am Chem Soc, 2014, 136: 12205-12208

12 Jiang Q, Chu Z, Wang P, et al. Planar-structure perovskite solar cells with efficiency beyond 21\%. Adv Mater, 2017, 29: 1703852

13 Kim M, Kim GH, Lee TK, et al. Methylammonium chloride induces intermediate phase stabilization for efficient perovskite solar cells. Joule, 2019, 3: 2179-2192

14 Jiang Q, Zhao Y, Zhang X, et al. Surface passivation of perovskite film for efficient solar cells. Nat Photonics, 2019, 13: 460-466

15 Luo X, Gao Y, Zhu P, et al. Record photocurrent density over $26 \mathrm{~mA} \mathrm{~cm}^{-2}$ in planar perovskite solar cells enabled by antireflective cascaded electron transport layer. Sol RRL, 2020, 4: 2000169

16 Deng K, Li L. Optical design in perovskite solar cells. Small Methods, 2020, 4: 1900150

17 Wang Y, Chen M, Li D, et al. Mesoporous silica hybrids as an antireflective coating to enhance light harvesting and achieve over $16 \%$ efficiency of organic solar cells. J Mater Chem C, 2019, 7: 14962-14969

18 Moghal J, Kobler J, Sauer J, et al. High-performance, single-layer antireflective optical coatings comprising mesoporous silica nanoparticles. ACS Appl Mater Interfaces, 2012, 4: 854-859
19 Keshavarz Hedayati M, Elbahri M. Antireflective coatings: Conventional stacking layers and ultrathin plasmonic metasurfaces, a mini-review. Materials, 2016, 9: 497

20 Chen D. Anti-reflection (AR) coatings made by sol-gel processes: A review. Sol Energy Mater Sol Cells, 2001, 68: 313-336

21 Raut HK, Ganesh VA, Nair AS, et al. Anti-reflective coatings: A critical, in-depth review. Energy Environ Sci, 2011, 4: 3779-3804

22 Tavakoli MM, Tsui KH, Zhang Q, et al. Highly efficient flexible perovskite solar cells with antireflection and self-cleaning nanostructures. ACS Nano, 2015, 9: 10287-10295

23 Dudem B, Heo JH, Leem JW, et al. $\mathrm{CH}_{3} \mathrm{NH}_{3} \mathrm{PbI}_{3}$ planar perovskite solar cells with antireflection and self-cleaning function layers. J Mater Chem A, 2016, 4: 7573-7579

24 Ye L, Zhang Y, Zhang X, et al. Sol-gel preparation of $\mathrm{SiO}_{2} / \mathrm{TiO}_{2} /$ $\mathrm{SiO}_{2}-\mathrm{TiO}_{2}$ broadband antireflective coating for solar cell cover glass. Sol Energy Mater Sol Cells, 2013, 111: 160-164

25 Ye L, Zhang X, Zhang Y, et al. Three-layer tri-wavelength broadband antireflective coatings built from refractive indices controlled silica thin films. J Sol-Gel Sci Technol, 2016, 80: 1-9

26 Cox JT, Hass G, Thelen A. Triple-layer antireflection coatings on glass for the visible and near infrared. J Opt Soc Am, 1962, 52: 965

27 Lien S, Wuu D, Yeh W, et al. Tri-layer antireflection coatings $\left(\mathrm{SiO}_{2} / \mathrm{SiO}_{2}-\mathrm{TiO}_{2} / \mathrm{TiO}_{2}\right)$ for silicon solar cells using a sol-gel technique. Sol Energy Mater Sol Cells, 2006, 90: 2710-2719

28 Kavakli IG, Kantarli K. Single and double-layer antireflection coatings on silicon. Turkish J Phys, 2002, 26: 349-354

29 Li X, Shen J. A scratch-resistant and hydrophobic broadband antireflective coating by sol-gel method. Thin Solid Films, 2011, 519: 6236-6240

30 Prené P, Priotton JJ, Beaurain L, et al. Preparation of a sol-gel broadband antireflective and scratch-resistant coating for amplifier blastshields of the French laser LIL. J Sol-Gel Sci Tech, 2000, 19: 533-537

31 Yang G, Chen C, Yao F, et al. Effective carrier-concentration tuning of $\mathrm{SnO}_{2}$ quantum dot electron-selective layers for highperformance planar perovskite solar cells. Adv Mater, 2018, 30: 1706023

32 MacLeod HA. Thin-Film Optical Filters. 4nd Edition. Boca Raton: CRC Press, 2010

33 Wang X, Zhao H, Cao Y, et al. Sol-gel preparation of laser damage resistant and moisture-proof antireflective coatings for KDP crystals. Langmuir, 2018, 34: 10262-10269

34 Koo H, Yi D, Yoo S, et al. A Snowman-like array of colloidal dimers for antireflecting surfaces. Adv Mater, 2004, 16: 274-277

35 Zhang XX, Cai S, You D, et al. Template-free sol-gel preparation of superhydrophobic ORMOSIL films for double-wavelength broadband antireflective coatings. Adv Funct Mater, 2013, 23: 4361-4365

36 Wang $\mathrm{H}$, Li F, Wang $\mathrm{P}$, et al. Chlorinated fullerene dimers for interfacial engineering toward stable planar perovskite solar cells with 22.3\% efficiency. Adv Energy Mater, 2020, 10: 2000615

37 Zimmermann E, Ehrenreich P, Pfadler T, et al. Erroneous efficiency reports harm organic solar cell research. Nat Photon, 2014, 8: $669-672$

Author contributions Wang Y synthesized and prepared the ARC coating. Wang $\mathrm{H}$, Chen $\mathrm{M}$ and Wang $\mathrm{P}$ fabricated the solar cell devices. Mao Y and Han W characterized the film morphology. Liu D and Wang $\mathrm{T}$ conceived the idea. All authors discussed the results and approved the manuscript. 
Conflict of interest The authors declare no competing interest.

Acknowledgements This work was supported by the Natural Science Foundation of Hubei Province (2019CFB575), and the National Natural Science Foundation of China (51861145101).

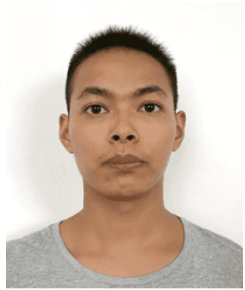

Yalun Wang received his BE degree in materials science and engineering from Hubei University, China in 2017. He is currently a Master student under the supervision of Dr. Dan Liu at Wuhan University of Technology, and is working on functional coatings to improve the efficiency and lifetime of solar cells.

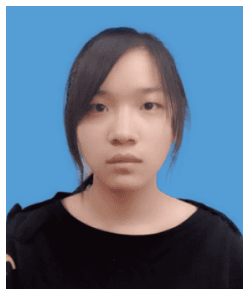

Hui Wang received her $\mathrm{BE}$ degree in materials science and engineering from Wuhan University of Technology, China in 2018. She is currently a $\mathrm{PhD}$ student under the supervision of Prof. Tao Wang at Wuhan University of Technology, and is working on perovskite solar cells.

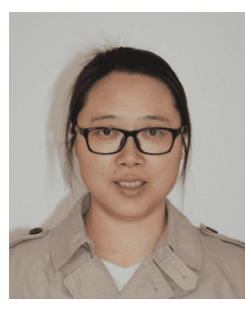

Dan Liu received her $\mathrm{PhD}$ in physics from the University of Surrey, U.K. in 2010. She was a postdoc research associate at the School of Physics and Astronomy, University of Leeds, UK before joining as an associate professor in 2014 in the School of Materials Science and Engineering, Wuhan University of Technology, China. Her research interests are functional thin films for optoelectronic devices.

\section{宽波段减反膜实现 23.9\%效率的平面异质结构钻 钛矿太阳能电池}

王亚伦 ${ }^{\dagger}$, 王茾 ${ }^{\dagger}$ 陈梦婷, 王胖, 毛宇超, 韩文娇, 王涛, 刘丹

摘要 虽然钙铁矿太阳能电池效率的发展令人鼓舞, 但是由于光反 射造成的器件基底界面的光子损失等问题仍然没有解决. 光管理 是降低反射损失并提高器件效率的有效途径. 因此, 我们设计了双 层减反膜以涂敷在 $\left(\mathrm{FAPbI}_{3}\right)_{x}\left(\mathrm{MAPbBr}_{3}\right)_{1-x}$ 钻铁矿太阳能电池的玻 璃基底外侧, 以期达到增加光吸收和提高器件效率的目的. 该研究 中的减反膜底层由硅聚合物构成，上层由氟代硅聚合物和六甲基 二硅氧烷/介孔二氧化硅纳米粒子复合而成. 通过精确调控上下层 的折射率及厚度, 我们在宽波段范围内实现了玻璃基底透过率从 最高约 $90 \%$ 显著提升到 $95 \%$. 在电池器件的玻璃基底外侧溶液涂膜 制备减反膜后, $\left(\mathrm{FAPbI}_{3}\right)_{x}\left(\mathrm{MAPbBr}_{3}\right)_{1-x}$ 钙钛矿太阳能电池在保持 填充因子和开路电压不变的情况下, 短路电流和效率分别从 $25.5 \mathrm{~mA} \mathrm{~cm}^{-2}$ 和 $22.7 \%$ 提高到 $26.5 \mathrm{~mA} \mathrm{~cm}^{-2}$ 和 $23.9 \%$. 本研究提出了 一种简单、高效的通过双层减反膜的光管理提高太阳能电池效率 的方法, 且此方法可拓展到其他类型太阳能电池体系. 